\title{
Corrigendum: Muscle-specific CRISPR/Cas9 dystrophin gene editing ameliorates pathophysiology in a mouse model for Duchenne muscular dystrophy
}

Niclas E. Bengtsson, John K. Hall, Guy L. Odom, Michael P. Phelps, Colin R. Andrus, R. David Hawkins, Stephen D. Hauschka, Joel R. Chamberlain \& Jeffrey S. Chamberlain

Nature Communications 8:14454 doi: 10.1038/ncomms14454 (2017); Published 14 Feb 2017; Updated 23 Jun 2017

This Article contains an error in Fig. 4, for which we apologize. In panel a, the image reporting dystrophin labelling following SaCas9 $\Delta 5253$ treatment was inadvertently duplicated from the corresponding image following SpCas $/ \Delta 5253$ treatment. The correct version of this figure appears below as Fig. 1. The raw data associated with this experiment are provided as a separate Supplementary Data file.

a
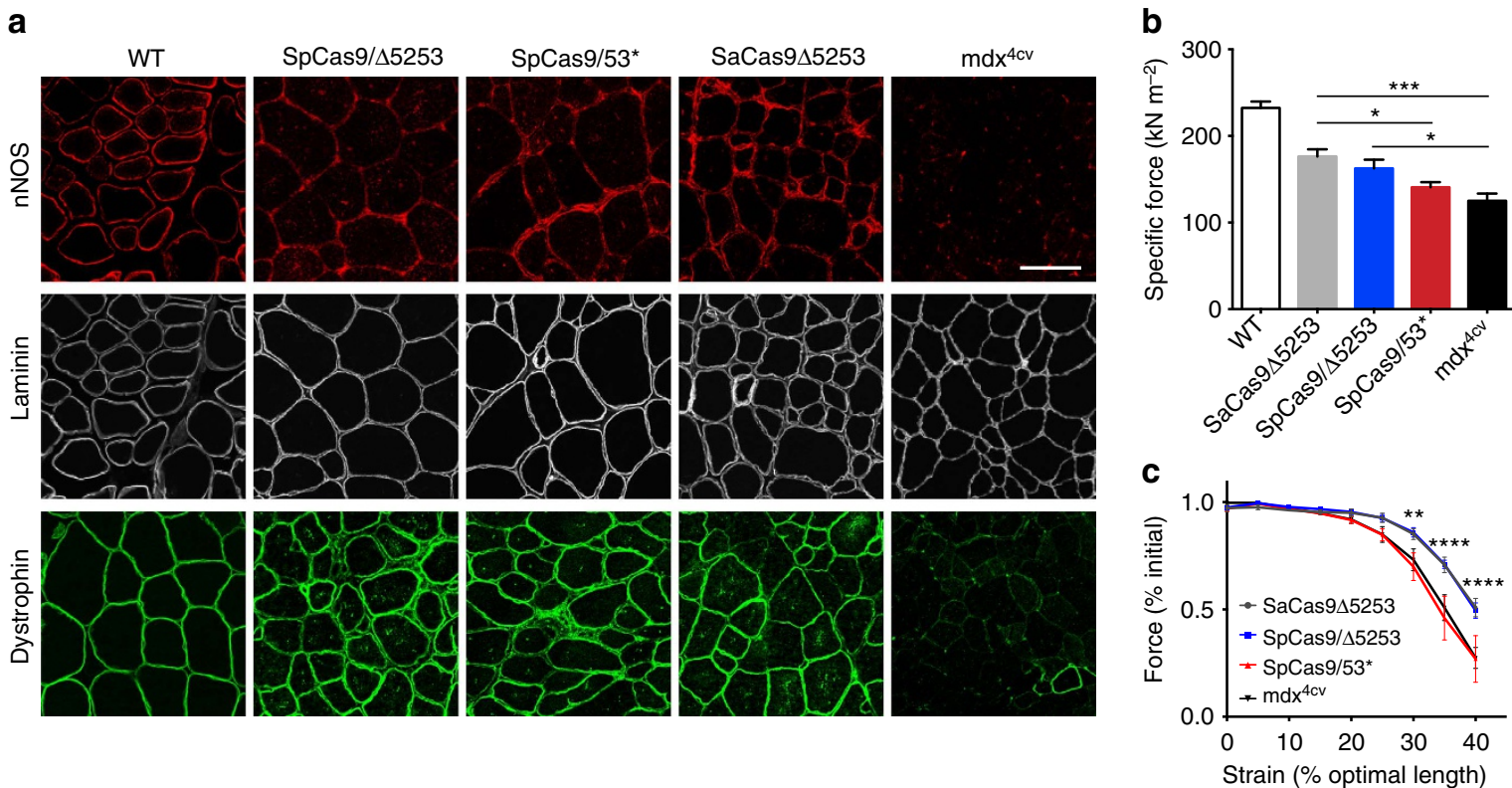

Figure 1 |

(i) Open Access This article is licensed under a Creative Commons Attribution 4.0 International License, which permits use, sharing, adaptation, distribution and reproduction in any medium or format, as long as you give appropriate credit to the original author(s) and the source, provide a link to the Creative Commons license, and indicate if changes were made. The images or other third party material in this article are included in the article's Creative Commons license, unless indicated otherwise in a credit line to the material. If material is not included in the article's Creative Commons license and your intended use is not permitted by statutory regulation or exceeds the permitted use, you will need to obtain permission directly from the copyright holder. To view a copy of this license, visit http://creativecommons.org/licenses/by/4.0/ 